DOI 10.31558/2307-2318.2019.2.6

УДК 314.7

Кримова М.О., к.е.н., старший науковий співробітник відділу дослідження ризиків у сфері зайнятості населення Інституту демографії та соціальних досліджень імені М.В. Птухи НАН України

\title{
ІНТЕГРАЦІЯ МІГРАНТІВ ЯК ІНСТРУМЕНТ ФУНКЦІОНУВАННЯ РИНКУ МІГРАЦІЙНИХ ПОСЛУГ КРАЇН СС
}

Статтю присвячено оцінці кількісно-якісних характеристик міграційних потоків та наявної інтеграційної політики в межах ринку міграційних послуг країн Європейського Союзу. В рамках дослідження здійснено групування країн Європейського Союзу за рівнем інтенсивності міграційних процесів, що дало змогу охарактеризувати якісні особливості мігрантів. Досліджено характер міграційних потоків за рівнем людського розвитку країн донорів. Опрацьовано основні принципи надання міграційних послуг в країнах ЄС. Окреслено усі інтеграційні послуги, які надаються, за блоками: адміністративно-юридичні, соціально-психологічні, трудові, освітні та фінансовоекономічні. Наведено приклади реалізації таких послуг по країнам членам асоціації у відповідності до статусу мігранта. Проаналізовано результати мовної, освітньої та трудової адаптації мігрантів за даними Євростату, а також досліджено відносну різницю у ризиках зубожіння родин-мігрантів та корінного населення.

Ключові слова: міграційні послуги, інтеграція, мігрант, Європейський союз, біженці, державна політика

\section{Крымова М.А. ИНТЕГРАЦИЯ МИГРАНТОВ КАК ИНСТРУМЕНТ ФУНКЦИОНИРОВАНИЯ РЫНКА МИГРАЦИОННЫХ УСЛУГ CTPAН ЕC}

Статья посвящена количественно-качественной оценке особенностей миграционных потоков и существующей интеграционной политики в рамках рынка миграционных услуг стран Европейского Союза. В ходе исследования осуществлена группировка стран Европейского Союза по уровню интенсивности миграционных процессов, что позволило охарактеризовать качественные особенности мигрантов. Изучен характер миграционных потоков в зависимости от уровня человеческого развития страны донора. Приведены основные принципы предоставления миграционных услуг в странах ЕС. Определены интеграционные услуги, предоставляемые по блокам: административно-юридические, социально-психологические, трудовые, образовательные и финансово-экономические. Рассмотрены примеры реализации таких услуг по странам членам ассоциации в соответствии со статусом мигранта. Проанализированы результаты языковой, образовательной и трудовой адаптации мигрантов по данным Евростата, а также исследована относительная разница в рисках обнищание семей мигрантов и коренного населения.

Ключевые слова: миграционные услуги, интеграция, мигрант, Европейский союз, беженцы, государственная политика 


\section{Krymova M.O. INTEGRATION OF MIGRANTS AS AN INSTRUMENT OF MIGRATION SERVICE MARKET OF THE EU}

The article is devoted to the estimation of quantitative and qualitative characteristics of migration flows and the existing integration policy within the framework of the market of migration services of the European Union countries. Within the framework of the research, the European Union countries were grouped according to the level of migration processes intensity, which made it possible to characterize the qualitative characteristics of migrants. The nature of migration flows is investigated by the level of human development of donor countries. The basic principles of the provision of migration services in the EU countries are elaborated. All integration services provided are outlined by blocks: administrative-legal, social-psychological, labor, educational and financial-economic. Examples of implementation of such the services in the member countries of the association are given in accordance with the status of migrants. The results of linguistic, educational and labor adaptation of migrants according to Eurostat are presented, as well as the relative differences in the risk of impoverishment of migrant families and indigenous peoples.

Keywords: migration services, integration, migrant, European Union, refugees, public policy

Постановка проблеми. В сучасному динамічному світі, що активно розвивається, одним 3 глобальних трендів, який є притаманним для всіх країн не залежно від рівня соціального та економічного розвитку $є$ активізація міграційних потоків. Бідність, військові конфлікти, прагнення кращого життя, пошук нових сфер зайнятості все більше притягує населення 3 країн третього світу до економічно розвинених центрів, одним 3 яких $є$ Європейський Союз. В зв'язку з цим, набуває значною актуальності пошук інструментів регулювання ринку міграційних послуг, який був би здатен: по-перше, захистити країну від неконтрольованих потоків мігрантів та зменшити ризики прояви терористичної агресії в Свропі; по-друге, створити можливості якнайшвидшої інтеграції мігрантів до місцевої спільноти, забезпечити можливості їх прихістку та адаптації у нових умовах.

Аналіз останніх досліджень і публікацій. Питаннями міграційної політики займається широке коло закордонних та вітчизняних науковців. Зокрема, істотний внесок у формування теоретико-методологічних основ дослідження міжнародних міграційних процесів зробили роботи: А. Дембіцької [1], О. Малиновської [2], О. Позняка [3], О. Савіцької [4], О. Святун [5] та інших. Проблемам регулювання міжнародних міграційних процесів та дослідження їх впливу на вітчизняні реалії присвячені роботи: Ю. Гуменюка [6], О. Дороніної [7], Е. Лібанової [8], М. Романюка [9], У. Садової [10], Л. Шаульської [11] та інших. Однак, в своїх роботах, вони не достатньо уваги приділяють питанням дослідження та критичної оцінки наявних форм та методів інтеграції мігрантів, розширенню переліку міграційних послуг, які надаються та $є$ ефективними.

Метою статті $\epsilon$ дослідження якісних характеристик міграційних потоків та наявної інтеграційної політики в межах ринку міграційних послуг країн Свропейського Союзу.

Виклад основного матеріалу. Глобальною тенденцією сьогодення є активізація міграційних процесів. Протягом останніх десяти років країни Європейського союзу стали одним з центрів тяжіння мігрантів. За період з 2008 по 2017 рік до країн асоціації прибуло більш ніж 38 мільйонів осіб, з яких близько 25\% залишились на постійне проживання, отримали громадянство або запросили тимчасовий прихісток [12]. 
Основним лідером за кількістю мігрантів в ЄС є Німеччина, чисельність мігрантів, які приймає ця країна $є$ достатньо стабільною, рекордна значення спостерігалось у 2015 році - 1, 543 млн.осіб (32,8\% від загальної кількості мігрантів прийнятих у цьому році країнами (С), у 2017 році спостерігається незначне зменшення міграційного притоку та дорівнює - 917,2 тис, осіб (20,6\% від загальної кількості мігрантів прийнятих у цьому році країнами (С) [12]. Поряд з Німеччиною, ключові позиції лідерів серед країн реципієнтів у СС посідають: Великобританія - 644 тис. осіб (14,5\% мігрантів); Іспанія 532,1 тис. осіб (майже 12\% мігрантів); Франція - 369,9 тис. осіб (8,3\% мігрантів) та Італія - 343,4 тис осіб (7,7\% мігрантів).

Досліджуючи структуру населення країн ЄС за країною походження, можна зробити висновок про наявність не лише активних міграційних процесів пов'язаних 3 зовнішнім припливом мігрантів (за даними 2017 року близько 4,5\% населення об'єднання, складали мігранти з країн, що не є членами ЄС), а й високу територіальну мобільність населення в межах СС. Усі країни європейського об'єднання можна поділити на три групи: 1) країни, що є більш привабливими для мігрантів 3 інших країн (це країни, які порівняно з іншими, мають менший економічний потенціал та мають полегшену форму перетину кордонів та отримання громадянства; характеризуються розгалуженою системою надання міграційних послуг); 2) країни, що є більш привабливими для здійснення внутрішньої мобільності (в більшості, це не великі країни, або країни економічні центри з достатньо складними умовами отримання громадянства); 3) країни, в рівній мірі привабливі, як для зовнішньої, так і для внутрішньої міграції (в більшості, це економічно розвинені країни, які мають сучасну розвинену систему міграційних послуг та розвинені спеціалізовані програми інтеграції мігрантів).

Так, базуючись на даних Євростату, до першої групи країн, можна віднести такі країни, як: Люксембург, Кіпр, Ірландія, Бельгія, Мальта. До другої групи, можна умовно віднести: Естонію, Латвію, Словенію, Португалію, Болгарію, Угорщину, Латвію, Хорватію та Польщу. Третя група країн, представлена Австрією, Німеччиною, Великобританією, Швецією, Нідерландами, Францією, Чехією та Фінляндією (рис. 1).

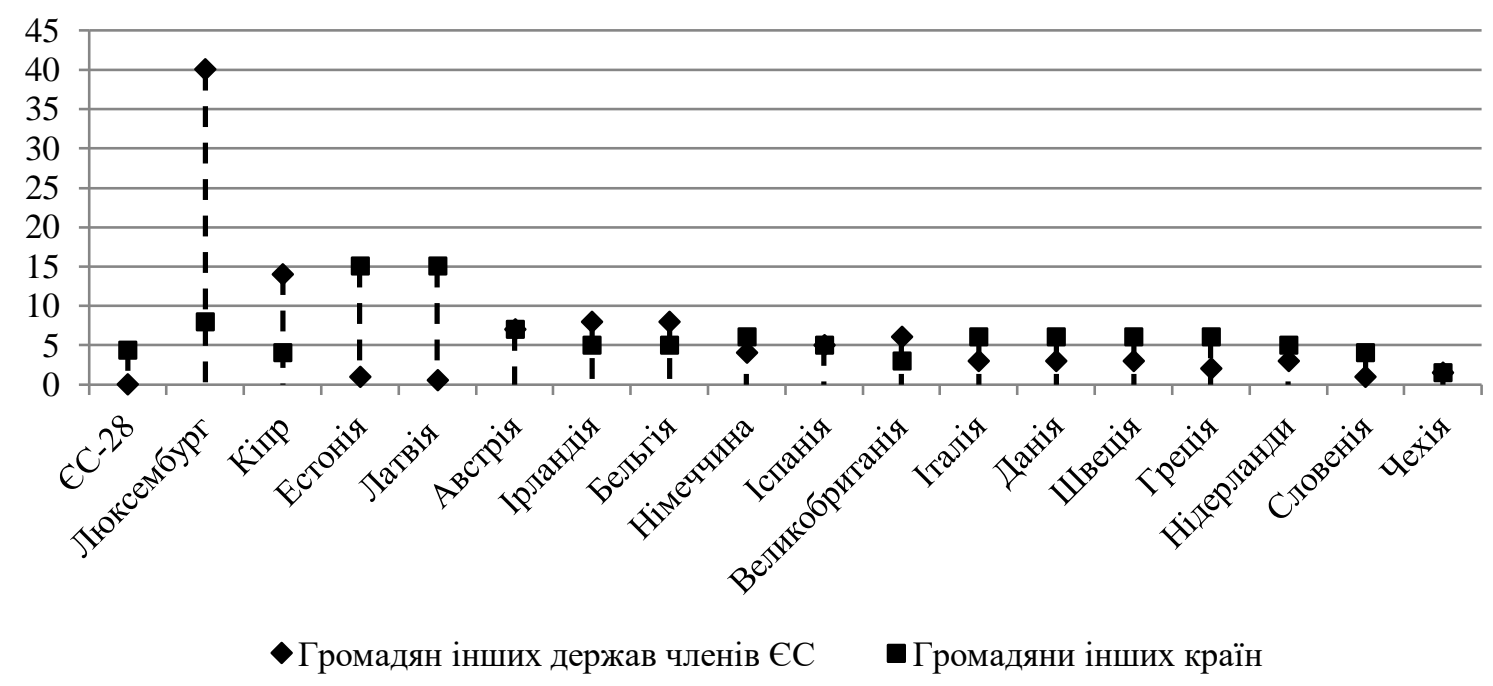

Рисунок 1 - Питома вага мігрантів за громадянством у загальній чисельності населення окремих країн СС [12] 
Нерівномірність міграційних потоків підкреслюється структурою мігрантів за рівнем людського розвитку країн їх походження. Більшість осіб, які переїхали до ЄС є народжені у країнах 3 високим або середнім рівнем розвитку (відповідно 41,2\% та $33,6 \%$ ). Однак, виокремлюється ряд країн в яких визначається привалювання мігрантів 3 країн, що мали низький та середній рівень людського розвитку, це: Бельгія, Італія, Нідерланди, Великобританія, Швеція та Кіпр (рис.2). Найбільша кількість мігрантів 3 країн, що мають дуже високий рівень людського розвитку, сконцентрована у Ірландії (26,7\%), Греції (11,5\%), Данії (10,6\%) та Люксембурзі (10,5\%). Специфічними країнами, 3 точки зору, якості мігрантів, які вони приймають, $є$ країни східної частини ЄС (Польща, Естонія, Словенія, Литва та Латвія), саме вони виступають найбільш активними донорами для осіб, які були народжені у країнах з середнім рівнем людського розвитку, в більшості це країни Свропи, які межують з СС та не входять до об’єднання (рис. 2).

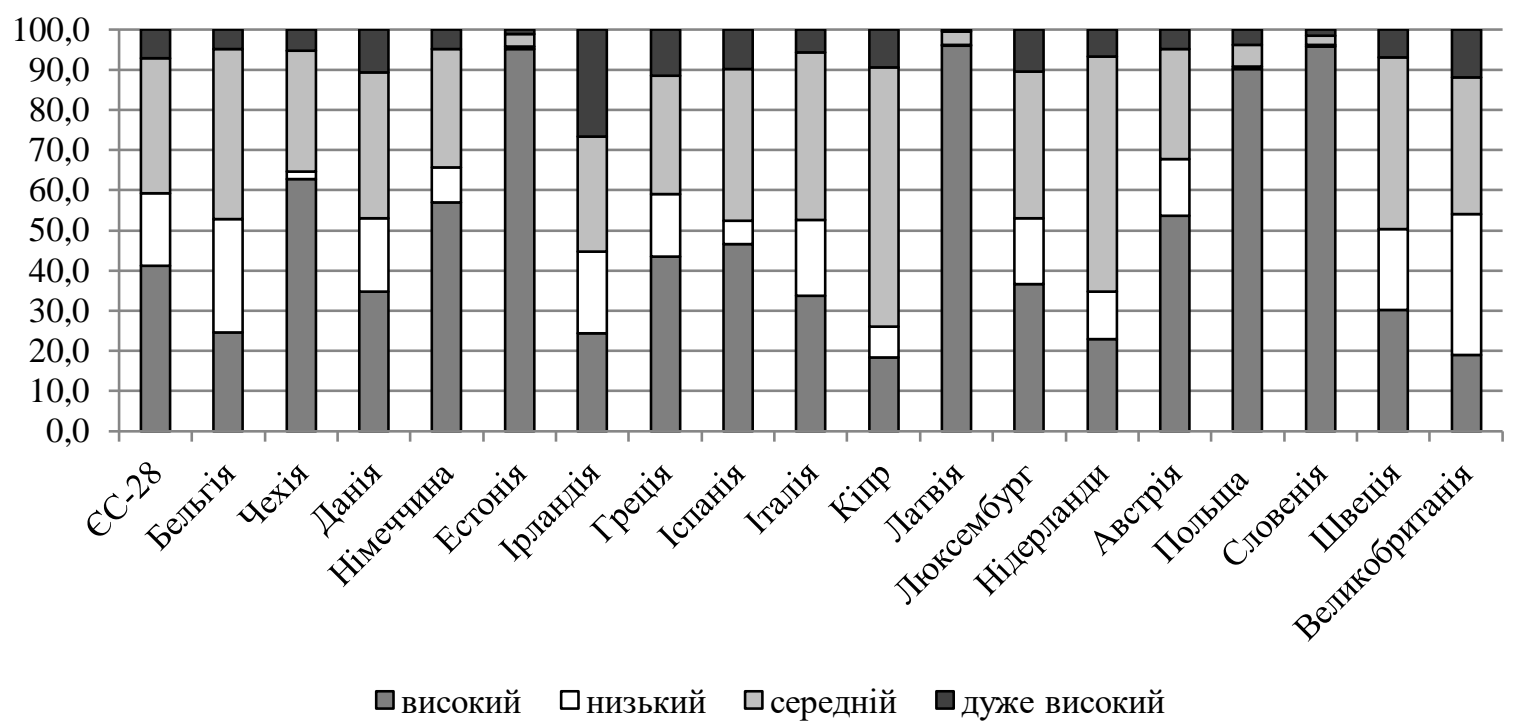

\section{Рисунок 2 - Мігранти в країнах СС за рівнем розвитку країни походження (крім мігрантів 3 інших країн ЄС та кандидатів до СС) [12]}

Характер інтеграційних програм, які реалізуються в країнах $\mathrm{CC}$, є різнобічним, вони формуються на основі наявної соціальної та економічної політики країни, структури осіб за статтю, віком, достатком та людським розвитком мігрантів, які прибувають до країни, а також основних причин міграції (пошук притулку, за сімейними обставинами або ж 3 метою працевлаштування чи навчання). Загальними є лише принципи їх надання, а саме [14]:

людської гідності - кожна людина має право власності та недоторканості особистого життя, право на цінування та повагу їі як особистості та етичного ставлення до неї;

збереження права на життя - кожна людина має право на життя, незалежно від дій які вона здійснила (даний принцип передбачає відмову країн $С С$ від використання смертної карти та вживання профілактичних заходів у ситуаціях, коли існує реальний та негайний ризик);

право на безпеку та життєдіяльність - кожна людина має право на доступ до базових благ країни в якій вона перебуває за умови виконання дотримання вимог інтеграційних програм; 
заборони дискримінації - кожна людина має рівні права, можливості та гідна на поважне ставлення незалежно від статі, віку, національності, кольору шкіри, етичного та соціального походження, генетичних особливостей, мови, релігії, політичних переконань, стану здоров'я, сексуальної орієнтації, тощо;

невиселення з країни - кожна людина має право на відмову від виселення або повернення до країни прибуття, якщо це будь-яким чином може загрожувати ії життю та гідності;

право притулку - кожна людина має право запросити притулку та захисту від прислідування, від власного імені або від імені своїх родичів (представників).

Досліджуючи практику інтеграції мігрантів в країнах $\mathrm{CC}$, усі наявні міграційні послуги у цій сфері можна поділити на такі групи: адміністративно-юридичні, соціальнопсихологічні, освітні, трудові та фінансово-економічні.

До адміністративно-юридичних послуг відносяться питання допуску мігрантів на територію країни перебування; надання та оформлення дозволу, щодо прав знаходження мігрантів на території держави; поновлення втрачених документів, які визнають особу; надання допомоги перекладача, задля покращення комунікації мігранта у випадку необхідності вирішення питань, що стосуються безпеки його життя та знаходження в країні прибуття; створення можливостей для отримання посвідки на проживання; інформаційна підтримка, щодо наявних інтеграційних програм в країні та можливостей їх включення до життя громади; надання юридичної допомоги з питань легалізації перебування мігранта на території країни; організація адміністративної та юридичної допомоги у випадку необхідності повернення мігранта до країни походження, тощо. Характер та перелік послуг, які надаються в цій сфері залежить від країни знаходження, а також причини 3 якої мігрант до неї прибуває. Наприклад, для осіб, що просять притулку, цей перелік послуг є ширшим ніж для осіб, які мігрують за сімейними обставинами (одруження на громадянині іншої країни, возз'єднання родини) або ж, в зв'язку з працевлаштуванням, навчанням. Так, наприклад мігранти першої групи, можуть скористуватися повним переліком адміністративно-юридичних послуг, не маючи при цьому першочергових законних обставин перетину кордону та перебування в країні. Мігранти ж другої групи, в більшості, повинні мати відповідні юридичні документи, які підтверджують їх статус знаходження у країні, найчастіше це трудова, навчальна віза або ж посвідка на тимчасове перебування в країни, яка надається відповідними державними органами (посольствами, консульствами).

Соціально-психологічні міграційні послуги, що реалізуються в країнах ЄС включають в себе ключові питання забезпечення мовної та культурної інтеграції, реалізація можливостей активної громадської позиції, здійснення міжкультурних заходів (адаптація до особливостей культури), надання психологічної допомоги особам, які постраждали від насилля, забезпечення медичного обстеження та підтримка належного рівня здоров'я, проведення відповідної вакцинації, для унеможливлення процесів поширення безпечних захворювань; проведення превентивних заходів щодо забезпечення соціальної безпеки та зменшення рівня злочинності серед мігрантів. За законодавством більшості країн $\mathrm{CC}$, кожен мігрант, який бажає залишитися (не дивлячись на причини міграції) повинен мати базові навички знання мови спілкування у країні перебування. Наприклад, у Німеччині, Бельгії, Швеції та Нідерландах при отриманні дозволу для в 'їзду в країни з можливістю постійного проживання мігрант повинен здати у посольстві країни іспит на знання мови та культури країни на рівні не нижче ніж В1. Окрім того, по прибуттю до країни проживання, мігрант, повинен відвідувати спеціалізовані курси з удосконалення мовних компетенцій. Особи ж які 
прибули до країни у якості біженців, отримують можливості вивчення мови на заняттях, які проводяться у міграційних центрах в яких вони тимчасово знаходяться до моменту видачі їм посвідки на дозвіл проживання в країні (по закінченню курсів, обов'язковою умовою $є$ здача іспиту з мови та культури країни на рівні не нижче ніж В1). В цілому знання мігрантом мови та культури країни перебування $€$ первинним показником ефективності його інтеграції. За даними Євростату середній рівень знання мови країни перебування, серед іноземців у СС-28 складає - 60\%. Найбільший рівень мовної інтеграції досягається у Німеччині, Нідерландах, Австрії, Великобританії, Данії та Швеції (варіюються у межах від 60 до 80\%). Найменша мовна адаптивність спостерігаєьбся у Румунії, Іспанії, Італії, Греції, Бельгії (варіюються у межах від 30 до $45 \%)$.

Переселяючись до країн Європейського союзу більшість мігрантів-біженців мають проблеми 3 фізичним та психологічним здоров'ям, які виникли на фоні умов їх попереднього проживання, негідного ставлення до їх особистості, недорозвиненістю системи охорони здоров'я у їх рідній країні. Задля зменшення загроз розповсюдження в Європі небезпечних вірусних захворювань та підтримки належного рівня людського розвитку мігрантів, у спеціалізованих міграційних центрах, які займаються питанням інтеграції біженців, кожен вимушений мігрант має право отримати кваліфіковану медичну та психологічну допомогу за рахунок коштів бюджету приймаючої країни.

Однією з найбільш гострих проблем, з якою зіткнулися країни Європи допускаючи до своїх кордонів біженців 3 країн третього світу, це загострення питань безпеки, поширення тероризму та зростання злочинності в країні. Так, у 2018 році кількість злочинів скоєних мігрантами склала $63 \%$ від загальної чисельності скоєних злочинів по країнах ЄC [12]. 3 метою, мінімізації ризиків в цій сфері, уряди країн проводять превентивні заходи за допомогою яких, по перше, регулюють допуск до кордону таких мігрантів, по друге, проводять соціально-психологічні та адаптивні програми, які дозволяють більш швидше адаптуватися мігрантам та дати їм можливості реалізації у новому суспільстві. Поширеною практикою $є$ інститут кураторства, який передбачає закріплення за проблемними мігрантами (родинами мігрантів) спеціальних фахівців (лайф-коучів), які допомагають їм у різних життєвих ситуаціях на новому місті.

Освітні міграційні послуги, включають в себе процедури залучення до освіти та адаптації молодших поколінь, отримання професії та підвищення кваліфікації старшого покоління, а також поширення серед мігрантів основних принципів освіти протягом життя.

Важливою сферою надання міграційних послуг, яка сприяє активній інтеграції мігрантів молодших поколінь у країнах $Є C €$ створення спеціалізованих програм навчання у школах. За європейськими стандартами кожна дитина з родини мігрантів повинна обов'язково відвідувати молодшу, середню та старшу школу. Мовна адаптація дітей здійснюється за двома основними напрямами, які різняться в залежності від комплексу чинників: країни їх перебування поточного знання дитиною мови, знання інших мов, тощо. Перша форма, це так зване «занурення», коли діти мігранти, навчаються разом 3 іншими дітьми, та вивчають державну мову країни у процесі комунікації з іншими. Друга форма, передбачає попереднє навчання дітей-мігрантів основам мови на спеціалізованих заняттях, а вже після цього, здійснення їх переводу до загальноосвітніх шкіл.

3 метою досягнення освітнього вирівнювання між мігрантами та корінними жителями у країнах СС активно розповсюджуються проекти залучення мігрантів до отримання професійної та вищої освіти. Так, наприклад, у Німеччині та Бельгії, особа 
яка не має вищої освіти, але на серії тестувань та співбесід показала високий рівень вмотивованості та інтелектуального розвитку може претендувати на отримання освітнього гранту для подальшого навчання за кошти держави. У Нідерландах, Данії, Італії та Чехії, діє активна система довгострокового кредитування навчання мігрантів, або ж часткової компенсації навчання. Вибір мігрантами напряму професійної підготовки здійснюється на основі наявного переліку затребуваних професій у регіоні перебування або ж на основі вже наявного професійного досвіду у певній сфері діяльності.

Трудові міграційні послуги. Основною метою міграційних послуг у сфері інтеграції $€$ забезпечення можливості отримання постійного доходу мігрантами, що є неможливим без їх працевлаштування. За даними Євростату в середньому 70\% мігрантів в країнах ЄC-28 є економічно активними, при цьому рівень економічної активності серед чоловіків $\epsilon$ набагато вищим ніж серед жінок (в середньому на 20\%). Країнами, мігранти в яких $\epsilon$ більш активними до зайнятості, є: Словенія, Чехія, Греція та Ірландія. Найменшою активність є у Бельгії, Данії, Нідерландах та Австрії (рис. 3) [12]. Різниця в показниках по країнам пов'язана з цілим комплексом факторів: по перше, поточним станом ринку праці країни; по-друге, наявними інтеграційними програмами у сфері фінансового забезпечення, які дають можливість не працювати окремими верствам мігрантів. Високий же лаг між економічно активними чоловіками та жінками, спостерігається, в зв'язку з тим, що більшість мігрантів є вихідцями з країн, в яких культура не дозволяє жінкам працювати.

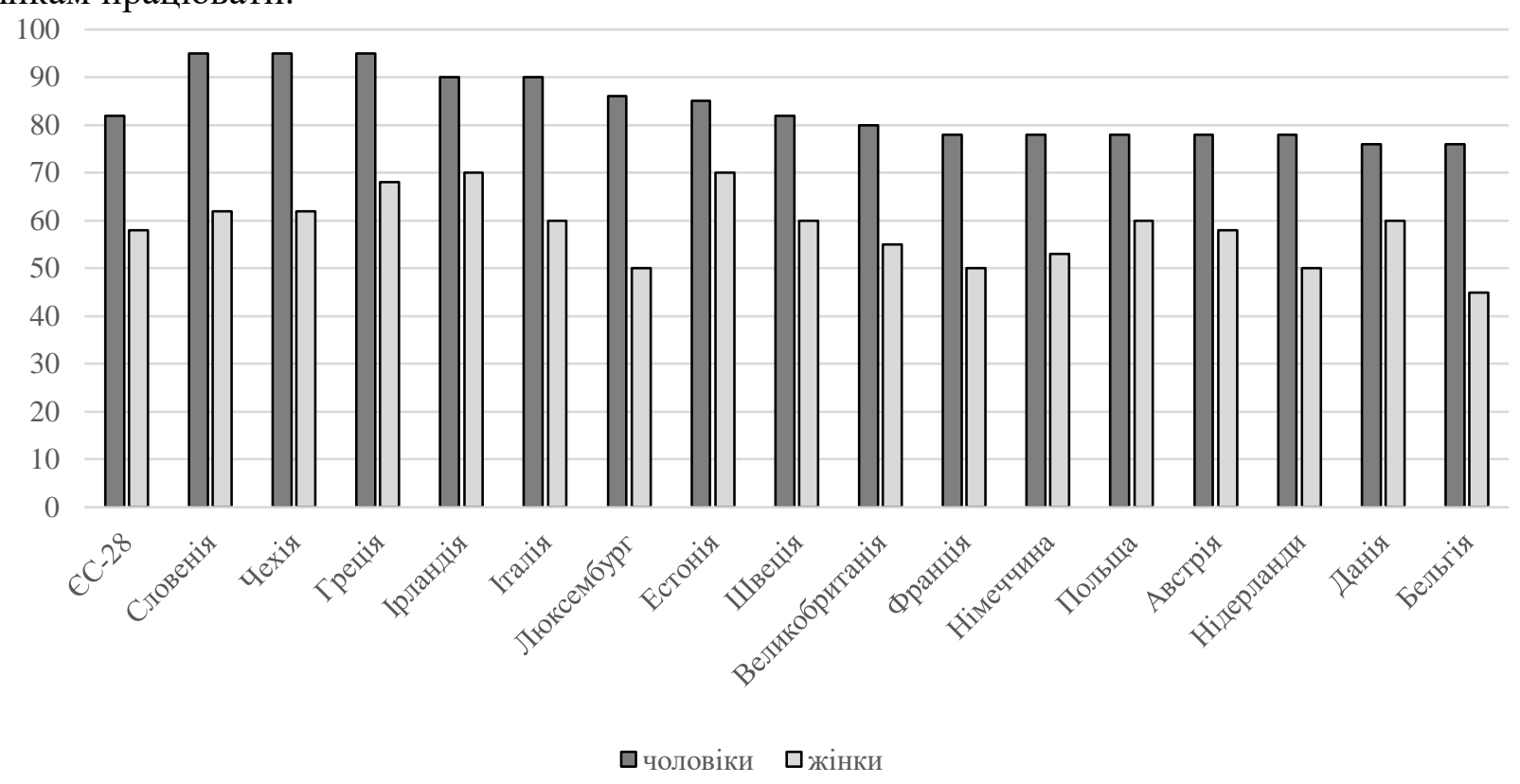

\section{Рисунок 3 - Рівень економічної активності мігрантів за статтю та країною проживання, \% [12]}

Задля забезпечення можливостей працевлаштування та боротьби з довготривалим безробіттям серед мігрантів (в СС показник відхилення довгострокового безробіття у мігрантів та постійного населення варіюється у межах від -8 в.п до 22 в.п), уряди держав членів впроваджують спеціальні програми, які включають освітні та економічні інструменти регулювання (проведення тренінгів з пошуку роботи та складання резюме; перенавчання мігрантів на затребувані на ринку праці професії; стимулювання роботодавців до прийому на роботу мігрантів з довгостроковим безробіттям; програми 
часткової та тимчасової зайнятості; залучення мігрантів до громадських робіт; зменшення рівня допомоги родинам біженцям, задля стимулювання їх до пошуку роботи, тощо). Окрім того, широко поширеною $є$ практика створення програм розвитку самозайнятості серед мігрантів, надання їм допомоги при первинному створенні власної справи та здійснення подальшої юридичної та інформаційної підтримки бізнесу. Ефективність надання таких послуг підкреслюють статистичні показники, так наприклад, у 2018 році близько 15\% працюючих мігрантів країн $€ C-28$, мали статус самозайнятих. Найбільший прошарок цього населення спостерігався у Чехії та Польщі (відповідно 43\% та 32\%), найменший у Австрії, Швеції та Люксембурзі (в межах 5\%) [12].

Фінансово-економічні міграційні послуги передбачають надання матеріальної та нематеріальної допомоги родинам мігрантів на покращення умов та рівня їх життя. В більшості країн ці послуги розповсюджуються на мігрантів-біженців. Відповідно до встановлених у ЄС правил, кожна країна створює відповідні умови для проживання родин, для цього, після надання мігрантам-біженцям посвідки на проживання, держава зобов'язується надавати їм щомісячну допомогу на оренду житла і купівлю приладдя та техніки першої необхідності. Основною умовою отримання цієї допомоги, є обов'язкове працевлаштування мігранта на рівні, що передує виникненню ризику зубожіння.

Існують в деяких країнах (Швеції, Бельгії, Польщі, Нідерландах) програми фінансової підтримки родин мігрантів, які дозволяють зменшувати ризики виникнення бідності в країні. За даними проведених міграційних досліджень урядом СС, середнє відхилення ризику зубожіння між родиною мігрантів та постійним населенням складає 10 в.П. Найбільші ризики зубожіння родин-мігрантів спостерігаються у Іспанії, Греції, Італії та Кіпрі (рис. 4), найменші у Польщі, Естонії, Латвії, Ірландії та Нідерландах (у перших двох він навіть має негативне значення).

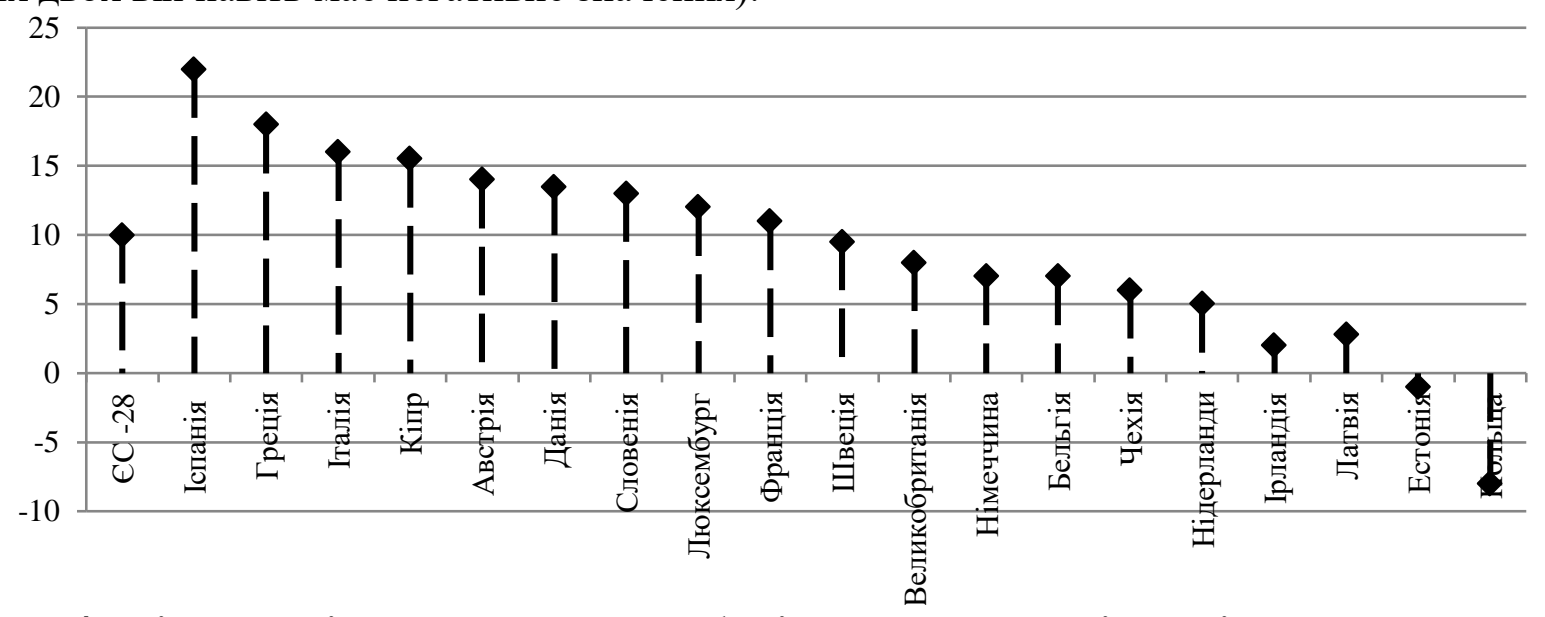

Рисунок 4 - Відсоток відхилення ризику зубожіння для родин мігрантів та родин 3 числа постійного населення [12]

Висновки. Дослідження досвіду надання міграційних послуг у сфер інтеграції мігрантів у країнах $€$ С показало достатньо високий рівень їх розвитку та різноманітності. Незалежно від наявної загальної політики СС, кожна країна, в залежності від внутрішніх пріоритетів обирає свій комплекс міграційних послуг, обираючи м'яку або жорстку політику по відношенню до мігрантів. Однак, не дивлячись на широке коло позитивного досвіду у сфері інтеграції мігрантів, актуальними залишаються питання забезпечення фізичної, соціальної, та політичної безпеки громадян, яка зменшується в зв'язку з масовим припливом мігрантів з країн третього світу, що мають свої культурні, релігійні 
та політичні вподобання агресивного характеру. Недостатньо ефективними вбачаються й наявні методи стимулювання мігрантів до зайнятості, що підтверджується наявним рівнем безробіття та достатку серед цієї групи населення.

\section{СПИСОК ВИКОРИСТАНИХ ДЖЕРЕЛ}

1. Дембіцька А. В. Основні етапи міжнародної міграції робочої сили / А. В. Дембіцька. // Вісник ОНУ імені I.І.Менчикова. - 2013. - Т. 18. - №4/1. - С. 149-152.

2. Міграційна політика Європейського союзу: виклики та уроки для України /O. А. Малиновська. - К. : НІСД, 2014. - 48 с.

3. Позняк О. Тенденции торговли людьми в Украине. [Електронний ресурс]. Режим доступу : http://www.carimeast.eu/media/exno/Explanatory\%20Notes_2013-66.pdf

4. Савіцька О. П. Особливості міграційних процесів населення в умовах глобалізації/ О. П. Савіцька, В. В. Цоньо // Науковий вісник НЛТУ України. - 2013. - Вип. 23.17. - С. 295-303.

5. Святун О.В. Свропейські механізми боротьби із торгівлею людьми: автореф. дис. на здобуття наук. ступеня канд. юрид. наук: 12.00.11 «Міжнародне право» / Олена Володимирівна Святун. - Київ, 2015. - 18 с.

6. Гуменюк Ю. П. Теоретичні аспекти дослідження впливу міжнародної міграції робочої сили на розвиток економічної системи [Текст] / Ю. П. Гуменюк, Г. П. Гоголь // Вісник національного університету «львівська політехніка». - 2009. - вип. 657. - с. 484 497.

7. Дороніна О.А, Присяжнюк А.А. Причини та наслідки трудової міграції української молоді / О.А. Дороніна, А.А. Присяжнюк // Праці П'ятнадцятої міжнародної наукової конференції студентів та молодих учених "Проблеми розвитку соціальноекономічних систем в національній та глобальній економіці"/Ред. кол. Хаджинов IB (голова) та ін.- Вінниця: ДонНУ, 2015.-320 с.

8. Лібанова Е. М. Зовнішні трудові міграції українців: масштаби, причини, наслідки. Демографія та соціальна економіка. №2(33). 2018. URL: https://doi.org/10.15407/dse2018.02 C. 11-27

9. Романюк М. Д. Закордонна трудова міграція та рееміграція в контексті національної безпеки України / М. Д. Романюк // Регіональна економіка. - 2016. - № 4. C. 22-30. - Режим доступу: http://nbuv.gov.ua/UJRN/regek_2016_4_5

10. Садова У.Я. Інституційне забезпечення функціонування транскордонного ринку міграційних послуг / У.Я. Садова, О.В. Махонюк // Регіональна економіка. - 2016. - № 4. - С. 31-38.

11. Шаульська Л.В. Сучасні проблеми соціально-трудової міграції. [Електронний pecypc]. - Режим доступу: http://ir.kneu.edu.ua/bitstream/handle/2010/2901/Shaulska.pdf; jsessionid=4289183F1DD5AC0490614BD571369E81? sequence $=1$

12. Офіційний сайт Євростату (база даних). [Електронний ресурс]. - Режим доступу: https://ec.europa.eu/eurostat

13. Офіційний сайт Європейського Союзу (програмні документи). [Електронний pecypc]. - Режим доступу: https://europa.eu/european-union/about-eu/institutions-bodies

14. Migrant integration - Migration data portal. [Електронний ресурс]. - Режим доступу: $\quad$ http://webcache.googleusercontent.com/search?q=cache:03BOiZGmIJ:migrationdataportal.org/ themes/migrant-integration $+\& \mathrm{~cd}=1 \& \mathrm{hl}=\mathrm{uk} \& \mathrm{ct}=\mathrm{clnk} \& \mathrm{gl}=\mathrm{ua}$ 